\title{
"Oncofertility" procedures in children and adolescents
}

Procedury "oncofertility" u dzieci i młodocianych

\author{
1,4 Marta Tarasiewicz, 2,4 Iwo Martynowicz, ${ }^{3}$ Paweł Knapp, ${ }^{4}$ Piotr Sieczyński
}

${ }^{1}$ Department of Perinatology of the University Clinical Hospital in Bialystok, Poland

${ }^{2}$ Department of Gynecology and Gynecological Oncology of the University Clinical Hospital in Bialystok, Poland

${ }^{3}$ University Center of Oncology of the University Clinical Hospital in Bialystok, Poland

${ }^{4}$ Gynecology and Obstetrics Infertility Treatment Center, KRIOBANK, Bialystok, Poland

\begin{abstract}
One of the most important elements associated with increase in oncological outcome in children is fertility preservation for future. It is obvious that chemo and radio therapy used in cancer treatment aim to destroy tumor cells, but they also impact healthy tissues. The negative influence of these types of therapy can be observed in every patient's organ. One of the most serious complication of oncological treatment is reproductive impairment. This determinates directly mental and social state of the patient as well as quality of life after the treatment, particularly in adolescent. Commonly used methods of fertility preservation in female children are: freezing ovarian tissue or unfertilized oocytes. Among male children freezing of testicular tissue or ejaculated sperm are conducted. Described methods of fertility preservation among children and adolescents are on the experimental stage and none of them provide $100 \%$ effectiveness.
\end{abstract}

\section{Key words:}

oncofertility, treatment, oncology, adolescent, infertility.

\section{Streszczenie}

Jeden z niezbędnych elementów związanych ze wzrostem skuteczności terapii onkologicznej wśród dzieci stanowi kwestia zabezpieczenia płodności u tych pacjentów w przyszłości. Oczywisty wydaje się fakt, że chemioterapeutyki i radioterapia stosowane w leczeniu nowotworów mają na celu niszczenie zmienionych chorobowo komórek i jednocześnie wpływają destrukcyjnie na zdrowe tkanki. Negatywny wpływ tego typu terapii można zaobserwować w każdym narządzie pacjenta. Jednym z poważniejszych powikłań leczenia onkologicznego (radiochemioterapeutycznego) jest zaburzenie funkcji rozrodczych. Determinuje to bezpośrednio stan psychiczny pacjenta, jego sytuację społeczną i jakość życia po zakończeniu leczenia, w szczególności dotycząc młodocianych. Powszechnie stosowanymi metodami zabezpieczenia płodności w populacji dzieci płci żeńskiej są: mrożenie tkanki jajnikowej i niezapłodnionych oocytów. Wśród dzieci płci męskiej przeprowadza się mrożenie tkanek jądra i plemników pozyskanych z ejakulatu. Opisane metody postępowania zapobiegającego utracie zdolności rozrodczych wśród dzieci znajdują się na etapie eksperymentalnym. Żadna z obecnie dostępnych metod zabezpieczania płodności nie zapewnia 100-procentowej gwarancji powodzenia.

\section{Słowa kluczowe:}

oncofertility, leczenie, onkologia, młodociani, niepłodność. 


\section{Introduction}

Every year, over 15,000 children and adolescents in the EU Member States are diagnosed with malignant tumours. According to the statistics of the National Cancer Register (KRN), 1000 new cases of cancer among children appear in Poland every year, averaging 12.2 cases per 100,000 in the population.

The most common cancers in children are leukemia (30\%), CNS tumors (17\%), lymphomas (15\%), sympathetic cancers $(7 \%)$ and kidney tumors $(9 \%)[1,2]$. The effectiveness of cancer therapy in children is constantly increasing, therefore the question of fertility preservation is becoming one of the key issues of modern medicine. Infertility caused by oncological treatment affects the quality of life of patients, especially adolescents. Loss of ability to have children or difficulties in conceiving are often the cause of psychological problems, which subsequent effects often manifest themselves in adaptation difficulties in society. In this context, infertility starts to be defined not only as a disease of sexual partners, but also as a disease entity with psycho-social characteristics. In recent years, this fact has become the basis for an attempt to combine advanced therapeutic techniques used in oncology, and techniques of preserving reproductive material in children and adolescents. Especially the latter group seems to be the so-called "target" population for the application of "oncofertility" techniques.

Recently observed development of embryology, molecular biology and assisted reproduction techniques has initiated a new direction in medicine - "oncofertility", as a scientific branch dedicated to female and male patients undergoing oncological therapy having a detrimental effect on reproductive functions.

Chemotherapy, surgical treatment and radiotherapy are the basic methods of treatment used in oncology. Knowledge of the biology of cancer, as well as the induction pathways of carcinogenetic pathways, has led to the most frequent use of combined therapy, which is a combination of these methods. The final choice of the method depends, however, on the type of cancer, the degree of its advancement and the patient's health condition. Radiotherapy and chemotherapy exposes female children to the risk of acute ovarian failure and the premature extinction of their activity. Among male children, the most common complication is testicular tissue damage and, as a consequence, permanent or temporary azoospermia, i.e. lack of sperm in the ejaculate $[3,4]$.

Preserving fertility in children in the face of diagnosed cancer is a distant problem that patients and their families are often unaware of. In response to the increasing demand for "Oncofertility" procedures, the Polish Society of Oncological Gynaecology issued Recommendations of the Fertility Preservation Working Group in Oncological, Hematological and Other Patients Treated With Gonadotoxic Therapies "ONCOFERTILITY" (GROF) [5]. The guidelines underline that it is possible to preserve fertility regardless of the age of the patient, and that the available methods should be discussed as early as possible, prior to the commencement of treatment. This can be effective in minimizing stress and improving the quality of patient's life in the future.

\section{Preserving fertility - female children}

The main sense of oncological treatment is to induce physical and chemical effect (depending on the method), which results in the final biological effect directed at the so-called "young elements" with high proliferation potential. In this context, any cancer treatment has a negative effect on the ovaries, uterus and/or pituitary gland, thus disturbing or accumulating the hypothalamic-pituitary-ovarian axis. The choice of therapy depends on the type of cancer, the patient's age and his condition. The toxicity of chemotherapy and its effect on gonads is dependent on many factors. The main factors include the age of the child and the doses of the drugs used - total and fractionated. The mechanism of action of chemotherapeutic agents is to act on DNA and prevent further cell division. Unfortunately, the degenerative effect is not limited only to cancer cells, but also affects healthy organs, including ovaries [6]. The most toxic to gonads chemotherapeutic agents include procarbazin, cytosine and alkylating agents. The therapies based on platinum derivatives and antimetabolites are less toxic to the ovaries. It is widely accepted that women are born with a finite number of primary vesicles and their total amount decreases with age and the impact of damaging factors. Decreasing the population of primary follicles plays a superior role in the patient's reproductive potential and fertility $[7,8]$. The most common side effect of cytostatic agents used in cancer chemotherapy is POF (premature ovarian failure - premature extinction of ovarian function) - depending on the total dose of the chemotherapeutic agent taken. The damaging effect is less extensive in small children due to a larger number of primary follicles at the start of therapy [9]. Importantly, there is no evidence that the ovary of prepubertal patients is more resistant to cytostatic damage. Regardless of the type of chemotherapeutic used, part of the patient's ovarian reserve will be lost irretrievably during the course of treatment, which will not always be visible in the clinical picture [10-13].

An extremely important element in planning radiation energy therapy is the assessment of the risk of loss of fertility in a child. If abdominal and pelvic radiation is used, there is an increased risk of damage to the uterus, fallopian tubes and ovaries. Oocytes are highly sensitive to radiation, and a dose of less than 2Gy may cause their complete destruction. Wallace et al. calculated that in the case of as many as $97 \%$ of women, who in childhood took the total radiation dose of the abdominal region in the range from 20-30 Gy, show ovarian failure $[14,12]$. It is estimated that radiotherapy accelerates premature menopause by an average of 10 years. It is important to state that the younger the patient is at the beginning of radiotherapy, the greater the ovarian reserve [8]. This prolongs the theoretical time for possible procreation in the future. In the opinion of many authors (Wallance et al., Teh et al., Brignardello et al.) it should be taken into account, that in patients who have managed to minimize adverse effects in the ovary area and maintain their function, radiation damage in the area of the uterus cannot be excluded, which in the future may result in the impossibility of becoming pregnant or contribute to miscarriages [14-16]. 
The vascular system and the flexibility of the uterus muscle are damaged at doses of 14-30 Gy. Studies by Vern-Gross et al. show that the radiation of tumors located in the head area radiation in the range from 35 to 40 Gy may lead to disorders of pituitary gland function [17]. This fact is extremely important especially during adolescence, and may manifest itself in delay or absence of menstruation. In old age it is a cause of hypogonadism due to deficiency of gonadotropin releasing hormone $(\mathrm{GnRH})$, which in consequence is one of the main factors of infertility. Patients with pelvic radiotherapy in childhood are at high risk of miscarriages and preterm births [16, 18-20].

Possibilities of using fertility protection therapy in female children are limited by the age of the patient. In the opinion of Loren et al. in girls before puberty, the only available treatment method, still in the experimental stage, is freezing the ovarian tissue [21]. The first successful procedure of cryopreservation of ovarian tissue was performed by Donnez et al. (2004) $[22,23]$. This procedure involves the excision, usually by laparoscopic method, of the whole ovary or its part. Then the outer layer of the ovary (the so-called ovarian cortex) is cut into small tissue strips and frozen. Tissues prepared in this way can be stored in the gaseous phase of nitrogen (temp. $-196^{\circ} \mathrm{C}$ ) for an unlimited period of time. The efficacy of this method in children has not been thoroughly studied. In the opinion of Meirow et al. and Gook et al., it is associated with too short time of observation of patients, from the moment of using this method of therapy for the first time [24, 25]. An unquestionable advantage of this method is the possibility to perform the procedure without the necessity of prior hormonal stimulation of the ovaries and delaying the oncological therapy. Implementation of this type of treatment entails the risk of complications related to the possibility of cancer cell transplantation and autoimmune rejection [26, 27]. The most recent studies carried out in Denmark by Jensen et al. (2015) have shown that out of 41 ovarian tissue transplants performed, the pregnancy rate was 31\% [28]. An alternative method of preserving fertility in children during adolescence is cryopreservation of unfertilized oocytes [29]. In order to obtain the desired number of egg cells, an earlier hormonal ovarian stimulation is necessary - it is routinely recommended to start treatment from the first days of menstruation, although studies by von Wolff et al. allow to start treatment regardless of the phase of the cycle [30]. This method does not have an adverse effect on the number of cells obtained and subsequently frozen. Hormonal ovarian stimulation aims at the production of mature egg cells. The time needed to carry out the whole procedure is about 14 days. This is a major disadvantage as it causes a postponement of the oncological treatment. The basic stimulation protocols are based on the administration of the $\mathrm{GnRH}$ antagonist. Then ovulation is induced with triptorelin and follicular maturation is further stimulated with gonadotropins. This method requires control of the level of hormones in the peripheral blood of the patient and evaluation of the size of ovarian follicles under the control of transvaginal (if such a procedure is possible) or trans-rectal ultrasonographic examination. Cells are obtained by means of ovarian puncture through the vagina, which requires general anaesthesia. Gametes obtained in this way are highly sensitive to temperature changes. Freezing of the obtained biological material takes place by vitrification, i.e. rapid cooling with the use of cryoprotectants. This prevents the formation of ice crystals in the cell during the freezing process [31-34]. This method was approved by the American Society for Reproductive Medicine (ASRM) in 2013 and the European Society of Human Reproduction and Embryology (ESHRE) in 2015, which changed its character from experimental to routine [35]. The effectiveness of this type of treatment was tested by Lawrenz et al. (2010) on a group of 11 women, $92 \%$ of oocytes survived the thawing process and $77 \%$ were subjected to effective in vitro fertilization. Pregnancy was obtained in 7 patients, 4 of whom gave birth [30, 36, 37].

Other approved methods of preserving fertility, including the freezing of fertilised egg cells, are not used in female children. This is due to the requirement to have a partner who can be the donor of the semen necessary for the fertilisation of oocytes.

In the context of undefined reproductive plans in children, this method is excluded and not taken into account when considering the available means of protecting reproductive potential in the discussed group of patients [38-40].

\section{Fertility preservation - male children}

Indications for cryopreservation of semen include all types of oncological treatment. Temporary infertility may occur in male children during puberty as a result of cytotoxic action of chemotherapeutics. Temporary deterioration of ejaculate value may last up to two years, and the lowest results are observed within six months after the end of treatment [41]. The extent of damage to male gonads caused by radiotherapy depends on the treatment regimen used. The radiation system and the total radiation dose may lead to irreversible changes in the testes. It has been found that even the lowest doses of 0.1-1.2 Gy have a negative effect on male sex cells and may lead to a temporary decrease in the number of sperm cells in semen (oligozoospermia) [42]. Permanent and irreversible azoospermia (no sperm in the semen) occurs at total doses of 4 Gy or fractionated 1.2 Gy. Testicular irradiation in boys at prepubertal age in doses exceeding 20 Gy leads to permanent damage to interstitial cells responsible for testosterone production (Leydig cells), while the function of these cells in sexually mature men is maintained even up to 30 Gy $[43,44]$. Leydig cells show higher resistance to radiation than sperm-producing epithelium of seminiferous tubules, therefore, radiation therapy included in the Oncofertility procedures in children is not usually associated with a complete impairment of reproductive functions in adult life [45]. In the group of men, as in the case of women, cranial radiation in the dose from 35 to 40 Gy may lead to dysfunction of the hypothalamo-pituitary system and reduce or completely impair the reproductive potential $[46,47]$.

The currently available fertility preservation options depend on the degree of sexual maturity of the patient. The most common and least invasive option in the group of male patients who have reached sexual maturity is cryopreservation of 
masturbated semen. If the ejaculate cannot be obtained, the material for freezing can be obtained by biopsy of testicles or epididymis [48]. It is an invasive method that allows for microsurgical aspiration of semen together with seminiferous tubules. Unfortunately, among patients with diagnosed cancer, the obtained genetic material is of poor quality [49]. Currently, it is possible to use the ICSI method - an intracytoplasmic sperm injection - which involves injecting a single sperm directly into an oocyte and creating an embryo. Therefore, cryopreservation of ejaculate or tissue obtained by biopsy is recommended regardless of the quality of the material obtained. Recent studies have shown that in a group of patients who have undergone cancer in childhood, sperm do not show signs of permanent DNA damage $[50,51]$. It is worth noting that in about $20 \%$ of boys in adolescence at Tanner II stage (average age 11.5 years) the process of sperm production (spermiogenesis) started, enabling cryopreservation of sperm cells. Therefore, it is recommended to all boys during puberty (with testicular volumes above 10-12 ml) to donate a semen sample before the oncological therapy [52]. Unfortunately, in some cancers (Hodgkin's lymphoma, lymphoma and testicular cancer) azoospermia (lack of sperm in the ejaculate) may occur long before diagnosis and treatment.

According to Schover et al., freezing semen obtained from ejaculate is the most effective method of preserving fertility and

\section{References}

1. Balcerska A. Epidemiologia chorób nowotworowych u dzieci. Forum Medycyny Rodzinnej 2009; 3: 61-63

2. Matysiak M. Rola lekarza rodzinnego w opiece nad dzieckiem z chorobą nowotworową. In: Hematologia w praktyce pediatrycznej. Wydawnictwo Lekarskie PZWL, Warszawa 2002; 127-128

3. Anderson RA, Mitchell RT, Kelsey TW, et al. Cancer treatment and gonadal function: experimental and established strategies for fertility preservation in children and young adults. Lancet Diabetes Endocrinol 2015; 3: 556-567. doi: 10.1016/S2213-8587(15)00039-X

4. Green DM, Sklar CA, Boice JD, et al. Ovarian failure and reproductive outcomes after childhood cancer treatment: results from the Childhood Cancer Survivor Study. J Clin Oncol 2009; 27: 23742381. doi: 10.1200/JCO.2008.21.1839

5. Jach R, Pabian W, Spaczyński R, et al. Recommendations of the Fertility Preservation Working Group in Oncological, Hematological and Other Patients Treated With Gonadotoxic Therapies "ONCOFERTILITY" (GROF) of the Polish Society of Oncological Gynecology. J Adolesc Young Adult Oncol 2017; 6: 388-395. doi: 10.1089/jayao.2017.00396.

6. Larsen EC, Muller J, Schmiegelow K, et al. Reduced ovarian function in long-term survivors of radiation- and chemotherapy-treated childhood cancer. J Clin Endocrinol Metab 2003; 88: 5307-5314. DOI: 10.1210/jc.2003-030352 does not cause any complications [53]. Currently for male children who have not reached puberty and sperm production processes (spermatogenesis) are not developed; only an experimental method involving the collection of immature testicular tissue shall be available. This tissue contains spermatogonia (stem cells) which can be cryopreserved. The efficacy of this method has not yet been confirmed [51].

\section{Summary}

Oncological treatment, especially chemotherapy and radiotherapy, have a significant influence on the reproductive potential of patients in childhood and adolescence. An important threat of this type of treatment is the complete loss of reproductive functions and their subsequent impact on the quality of life and psychological conditions. None of the discussed methods allows for $100 \%$ preservation of fertility. Therefore, it is important that regardless of the age of the patient, the doctor should propose the use of currently available methods to preserve the reproductive potential. It is worth noting that in the case of children and minors who do not have legal capacity, the decision to undertake actions aimed at preserving fertility should be taken together with the minor patient and in consultation with his legal guardian.
7. Howell S, Shalet S. Gonadal damage from chemotherapy and radiotherapy. Endocrinol Metab Clin North Am 1998; 27: 927-943.

8. Wallace WH, Kelsey TW. Human ovarian reserve from conception to the menopause. PLoS One 2010; 5: e8772. doi: 10.1371/journal. pone. 0008772

9. Anderson RA, McLaughlin M, Wallace WH, et al. The immature human ovary shows loss of abnormal follicles and increasing follicle developmental competence through childhood and adolescence. Hum Reprod 2014; 29: 97-106. doi: 10.1093/humrep/det388

10. Hershberger PE, Finnegan L, Pierce PF, et al. The decision-making process of young adult women with cancer who considered fertility cryopreservation. J Obstet Gynecol Neonatal Nurs 2013; 42 : 59-69. doi: 10.1111/j.1552-6909.2012.01426.x

11. Klock SC, Zhang JX, Kazer RR. Fertility preservation for female cancer patients: early clinical experience. Fertil Steril 2010; 94: 149-155. doi: 10.1016/j.fertnstert.2009.03.028

12. Wallace $W H$, Thomson AB, Kelsey TW. The radiosensitivity of the human oocyte. Hum Reprod 2003; 18: 117-121. doi: 10.1093/humrep/deg016

13. Wenzel L, Dogan-Ates A, Habbal R, et al. Defining and measuring reproductive concerns of female cancer survivors. J Natl Cancer Inst Monogr 2005; 34: 94-98. doi: 10.1093/jncimonographs/Igi017

14. Brignardello E, Felicetti F, Castiglione A, et al. Gonadal status in long-term male survivors of childhood cancer. J Cancer Res Clin Oncol 2016; 142: 1127. doi: 10.1007/s00432-016-2124-5 
15. Teh WT, Stern C, Chander S, Hickey M. The impact of uterine radiation on subsequent fertility and pregnancy outcomes. Biomed Res Int 2014; 2014: 482968. doi: 10.1155/2014/482968

16. Wallace $\mathrm{WH}$, Thomson $\mathrm{AB}$, Saran $\mathrm{F}$, et al. Predicting age of ovarian failure after radiation to a field that includes the ovaries. Int $\mathrm{J}$ Radiat Oncol Biol Phys 2005; 62: 738-744. doi: 10.1016/j.ijrobp.2004. 11.038

17. Vern-Gross T, Bradley J, Ronny L, et al. Fertility in childhood cancer survivors following cranial irradiation for primary central nervous system and skull base tumors. Radiotherapy and Oncology 2015; 117: 195-205. doi: 10.1016/j.radonc.2015.10.001

18. Barton SE, Najita JS, Ginsburg ES, et al. Infertility, infertility treatment, and achievement of pregnancy in female survivors of childhood cancer: a report from the Childhood Cancer Survivor Study cohort. Lancet Oncol 2013; 14: 873-881. doi: 10.1016/S14702045(13)70251-1

19. Critchley HOD, Wallace WHB, Shalet SM, et al. Abdominal irradiation in childhood; the potential for pregnancy. Br J Obstet Gynaecol 1992; 99: 392-394. doi: 10.1111/j.1471-0528.1992.tb13755.x

20. Carter J, Rowland K, Chi D, et al. Gynecologic cancer treatment and the impact of cancer-related infertility. Gynecol Oncol 2005; 97 : 90-95. doi: 10.1016/j.ygyno.2004.12.019

21. Loren AW, Mangu PB, Nohr Beck L, et al. Fertility preservation for patients with cancer: American Society of Clinical Oncology Clinical Practice Guideline Update. J Clin Oncol 2013; 31: 2500-2510. doi: 10.1200/JCO.2013.49.2678

22. Donnez, J, Dalmans MM. Ovarian cortex transplantation: 60 reported live births brings the success and worldwide expansion of the technique towards routine clinical practice. J Assist Reprod Genet 2015; 32: 1167-1170. doi: 10.1007/s10815-015-0544-9

23. Donnez J, Dalmans MM, Demylle D, et al. Livebirth after orthotopic transplantation of cryopreserved ovarian tissue. Lancet 2004; 364: 1405-1410. doi: 10.1016/S0140-6736(04)17222-X

24. Gook DA, Edgar DH, Stern C. The effects of cryopreservation regimens on the morphology of human ovarian tissue. Mol Cell Endocrinol 2000; 169: 99-103. doi: 10.1016/s0303-7207(00)00360-9

25. Meirow D, Levron J, Eldar-Geva T, et al. Pregnancy after transplantation of cryopreserved ovarian tissue in a patient with ovarian failure after chemotherapy. New Eng J Med 2005; 353: 318-321. doi: 10.1056/NEJMc055237

26. Demeestere I, Simon P, Dedeken L, et al. Live birth after autograft of ovarian tissue cryopreserved during childhood. Hum Reprod 2015; 30: 2107-2109. doi: 10.1093/humrep/dev128

27. Dolmans M, Luyckx V, Andersen C, et al. Risk of transferring malignant cells with transplanted frozen-thawed ovarian tissue. Fertil Steril 2013; 99:1514-1522. doi: 10.1016/j.fertnstert.2013.03.027

28. Jensen AK, Kristensen SG, Macklon KT, et al. Outcomes of transplantation of crypreserved ovarian tissue to 41 women in Denmark. Hum Reprod 2015; 30: 2838-2845. doi: 10.1093/humrep/dev230

29. Borini A, Bianchi V. Cryopreservation of mature and immature oocytes. Clin Obstet Gynecol 2010; 53: 763-774. doi: 10.1097/ GRF.0b013e3181f96f01

30. von Wolff M, Thaler CJ, Frambach T, et al. Ovarian stimulation to cryopreserve fertilized oocytes in cancer patients can be started in the luteal phase. Fertil Steril 2009; 92: 1360-1365. doi: 10.1016/j. fertnstert.2008.08.011
31. Anderson RA, Wallace WH. Fertility preservation in girls and young woman. Clin Endocrinal (Oxf) 2011; 75: 409-419. doi: 10.1111/j.1365-2265.2011.04100.x

32. Levi Setti PE, Porcu E, Patrizio P, et al. Human oocyte cryopreserration with slow freezing versus vitrification, Results from the National Italian Registry data, 2007-2011. Fertil Steril 2014; 102: 90-95. doi: 10.1016/j.fertnstert.2014.03.052

33. Oktay K, Cil AP, Bang H. Efficiency of oocytecryopreservation: A meta-analysis. Fertil Steril 2006; 86: 70-80. doi: 10.1016/j.fertnstert.2006.03.017

34. Rodriguez-Wallberg KA, Oktay K. Fertility preservation during cancer treatment: Clinical guidelines. Cancer Manag Res 2014; 6: 105-117. doi: 10.2147/CMAR.S32380

35. von Wolff M, Germeyer A, Nawroth F. Fertility preservation for nonmedical reasons - controversial but increasingly common. Dtsch Arztebl Int 2015; 112: 27-32. doi: 10.3238/arztebl.2015.0027

36. Lawrenz B, Jauckus J, Kupka M, et al. Efficacy and safety of ovarian stimulation before chemotherapy in 205 cases. Fertil Steril 2010; 94: 2871-2873. doi: 10.1016/j.fertnstert.2010.06.054

37. Lawrenz B, Jauckus J, Kupka MS, et al. Fertility preservation in $>$ 1,000 patients: patient's characteristics, spectrum, efficacy and risks of applied preservation techniques. Arch Gynecol Obstet 2011; 283: 651-656. doi: 10.1007/s00404-010-1772-y

38. Nieman CL, Kinahan KE, Yount SE, et al. Fertility preservation and adolescent cancer patients: lessons from adult survivors of childhood cancer andtheir parents. Cancer Treat Res 2007; 138 : 201-217.

39. Stensheim H, Cvancarova M, Møller B, et al. Pregnancy after adolescent and adult cancer: a population-based matched cohort study. Int J Cancer 2011; 129: 1225-1236. doi: 10.1002/ijc.26045

40. Wallace WHB, Anderson RA, Irvine DS. Fertility preservation for young patients with cancer: who is at risk and what can be offered? Lancet Oncol 2005; 6: 209-218. doi: 10.1016/S14702045(05) 70092-9

41. Schover LR, Brey K, Lichtin A, et al. Oncologists' attitudes and practices regarding banking sperm before cancer treatment. J Clin Oncol 2002; 20: 1890-1897. doi: 10.1200/JCO.2002.07.174

42. Moss J, Choi A, Keeter M, Brannigan R. Male adolescent fertility preservation. Fertil Steril 2016; 105: 267-273. doi: 10.1016/j.fertnstert.2015.12.002

43. Coura C, Modesto P. Impact of late radiation effects on cancer survivor children: an integrative review. Einstein (São Paulo) 2016; 14 : 71-76. doi: 10.1590/S1679-45082015RW3102

44. Shalet SM, Tsatsoulis A, Whitehead E, et al. Vulnerability of the human Leydig cell to radiation damage is dependent upon age. J Endocrinol 1989; 120: 161-165. doi: 10.1677/joe.0.1200161

45. Kim SS, Yin H, Gosden RG. Cryobanking of ovarian and testicular tissue for children and young adults. In: Preservation of Fertility. Tulandi T, Gosden RG (eds.). Taylor \& Francis, London 2004; 157-173.

46. Romerius P, Stíhl O, Moëll C, et al. Sperm DNA integrity in men treated for childhood cancer. Clin Cancer Res 2010; 16: 38433850. doi: 10.1158/1078-0432.CCR-10-0140

47. Rowley MJ, Leach DR, Warner GA, Heller CG. Effect of graded doses of ionizing radiation on the human testis. Radiat Res 1974; 59: 665-678. 
48. Zapzalka DM, Redmon JB, Pryor JL. A survey of oncologists regarding sperm cryopreservation and assisted reproductive techniques for male cancer patients. Cancer 1999; 86: 1812-1817. doi: 10.1002/ (sici)1097-0142(19991101)86:9<1812::aid-cncr24>3.0.co;2-।

49. Agarwal A, Allamaneni SSR. Disruption of spermatogenesis by the cancer disease process. J Natl Cancer Inst Monogr 2005; 34: 9-12. doi: 10.1093/jncimonographs/lgi005

50. Hsiao W, Stahl PJ, Osterberg EC, et al. Successful treatment of postchemotherapy azoospermia with microsurgical testicular sperm extraction: the Weill Cornell experience. J Clin Oncol 2011; 29: 1607-1611. doi: 10.1200/JCO.2010.33.7808
51. Muller J, Sonksen J, Sommer P, et al. Cryopreservation of semen from pubertal boys with cancer. Med Pediatr Oncol 2000; 34: 191-194.

52. Williams DH. Sperm banking and the cancer patient. Ther Adv Urol 2010; 2: 19-34. doi: 10.1177/1756287210368279

53. Schover LR, Brey K, Lichtin A, et al. Knowledge and experience regarding cancer, infertility, and sperm banking in younger male survivors. J Clin Oncol 2002; 20: 1880-1889. doi: 10.1200/ JCO.2002.07.175 